\title{
Pengembangan Media Pembelajaran Berbasis Mobile Learning Pada Mata Pelajaran Dasar Listrik Dan Elektronika Sekolah Menengah Kejuruan
}

\author{
Mery Sumiati ${ }^{1,2 *}$, Fahmi Rizal' ${ }^{2}$, Muhammad Anwar ${ }^{2}$ \\ ${ }^{1}$ Sekolah Menengah Kejuruan Negeri 4 Pariaman \\ 1,2Prodi Magister Pendidikan Teknologi Kejuruan, Fakultas Teknik, Universitas Negeri Padang \\ *Corresponding author, e-mail: merysumiati04@gmail.com
}

\begin{abstract}
Abstrak - Dalam proses pembelajaran materi Dasar Listrik dan Elektronika (DLE), siswa terkendala dalam memahami materi pelajaran, karena belum adanya media pendukung pembelajaran yang memadai untuk membantu siswa dalam memahami materi pembelajaran. Berdasarkan masalah tersebut adapat disimpulkan bahwa pembelajaran membutuhkan dukungan media yang cocok dan memadai. Penelitian ini bertuujuan dihasilkannya media pembelajaran berbasis mobile learning yang dapat membantu siswa dalam memahami materi pembelajaran mata pelajaran DLE. Pada penelitian ini digunakan metode penelitian dan pengembangan. Tahapan penelitian mengikut kepada tahapan yang dikembangakan oleh Borg \& Gall, yang tersusun dalam sepuluuh langkah penelitian. Instrumen Angket gigunakan sebagai instrument penelitian. Angket validasi diberikan kepada ahli materi dan ahli media. Angket untuk mengukur praktikalitas diberikan kepada siswa dan guru mata pelajaran yang bersangkutan. Untuk mengukur efektivitas digunakan desain penelitian Quasi ekperiment dengan cara membandingkant nilai siswa pada kelas eksperimen dan kelas kontrol. Pada penelitian pengembangan ini diperoleh hasil media pembelajaran berbasis mobile learning pada mata pelajaran Dasar Listrik dan Elektronika yang sudah teruji kevalidan, kepraktisan dan keefektifannya. Validasi media oleh ahli media pada aspek isi, tujuan, instuksional dan teknis masuk kategori valid. Validasi materi oleh ahli materi pada aspek materi dan pembelajaran termasuk kategori valid. Nilai praktikalitas berasal dari hasil angket respon guru dan respon siswa dikategorikan sangat praktis. Dari nilai posttest siswa diperoleh hasil efektifitas dan disimpulkan terdapat perbedaan yang signifikan antara nilai kelas eksperimen dan kelas kontrol.
\end{abstract}

Kata Kunci : Media Pembelajaran, mobile learning, Dasar Listrik dan Elektronika.

Abstract—In the learning process of basic electricity and electronics subject, students face problems in understanding the material because it is considered as difficult without supported of adequate media. Therefore, teaching learning process needs to be supported by suitable and adequate media. The purpose of this research is mobile based learning media that is valid, practical and effective for Basic Electricity and Electronics subjects. The method of this research is Research and Development $(R \& D)$. This research and development used the Borg and Gall model that consists of several stages. The instrument used in this research is validation questionnaire that was given to material experts and media experts. Practical questionnaire was given to students and teacher. Quasi experiment research design used to measure the effectiveness by comparing student learning outcomes of the experimental class and the control class. The results obtained from this research development is a learning media based on mobile learning in the Basic Electricity and Electronics subjects. Media validation by media experts on content, purpose, instructional and technical aspects is in the valid category. Material validation by material experts on the material and learning is a valid category. The practical value of the results of the questionnaire, teacher responses and student responses are categorized very practical. From the posttest scores students get the results of the effectiveness and concluded that a significant value between the experimental class and the control class

Keyword: Learning Media, mobile learning, Basic Electricity and Electronics 


\section{Pendahuluan}

Pendidikan adalah proses mempengaruhi siswa untuk menggali potensi kemampuan atau keterampilan mendasar secara intelektual dan emosional yang ada agar dapat bermanfaat pada lingkungannya [1-3] . Pendidikan kejuruan adalah tingkatan pendidikan yang direncanakan mempersiapkan tenaga kerja dengan keahlian tertentu untuk memasuki dunia kerja [4-6]. Oleh karena itu pendidikan di SMK diharapkan untuk mampu mempersiapkan siswa menjadi individu yang memiliki produktifitas, menghasilkan sesuatu yang sesuai dengan bidang keahlian melalui proses pendidikan di sekolah. Materi yang diajarkan di SMK tidak hanya memberikan pengetahuan secara teori namun juga di bidang keterampilan yang dapat diterapkan pada keadaan tertentu di lapangan kerja.

Pada kurikulum 2013 ditetapkan bahwa mata pelajaran DLE merupakan mata pelajaran dasar yang dipelajari oleh sisawa. Pada mata pelajaran DLE dipelajari beberapa materi seperti satuan Besaran pada kleistrikan, komponen dasar kelistrikan, hukum-hukum yang diterapkan kelistrikan dan elektronika, alat ukur yang digunakan pada listrik dan elektronika, alat pengaman dan instalasi listrik dan elektronika, sifat dan aturan rangkaian seri, paralel dan campuran dari tahanan dan tegangan, prinsip kemagnetan, sumber tegangan listrik, dan komponen pasif RLC. Pada konsep pembelajaran pada kurikulum 2013 dikembangkan model pembelajaran siswa aktif, guru hanya mengarahkan agar proses tujuan pembelajaran tercapai. Proses pembelajaran dikelas perlu ditunjang dengan beberapa metode yang dilengkapi dengan media pembelajaran. Penerapan media dalam proses pembelajaran akan menghasilkan kualitas yang berpengaruh proses pembelajara [7]. Penggunaan media pembelajaran didalam kelas mampu meningkatkan atau membantu dalam penerapan metode belajar di dalam kelas.

Media pembelajaran sudah diterapkan pada proses pembelajaran yaitu berupa media power point. Namun siswa masih terkendala dalam memahami materi pembelajaran. Hal ini disebabkan karena media pembelajaran belum dapat digunakan oleh siswa untuk nelajar diluar jam pelajaran tatap muka di kelas. Media pembelajaran yang belum beragam membuat siswa merasa bosan untuk belajar. Sehingga masih ada siswa yang belum lulus Kriteria Ketuntasan Minimal (KKM) pada mata pelajaran DLE. Persentase Hasil Belajar DLE siswa dapat dilihat pada tabel berikut :

Tabel 1. Persentase Nilai DLE Siswa Tahun Pelaajaran 2018/2019

\begin{tabular}{|c|c|c|c|c|c|}
\hline \multirow{2}{*}{ Kelas } & \multirow{2}{*}{$\begin{array}{c}\text { Total } \\
\text { Siswa }\end{array}$} & \multicolumn{2}{|c|}{$\begin{array}{c}\text { Nilai } \geq(75 \\
\text { KKM })\end{array}$} & \multicolumn{2}{c|}{ Nilai < $(75$ KKM $)$} \\
\cline { 3 - 6 } & & Jumlah & Persen & Jumlah & Persen \\
\hline $\begin{array}{c}\text { X } \\
\text { TEI }\end{array}$ & 27 & 11 & 40,74 & 16 & 59,26 \\
\hline $\begin{array}{c}\text { X } \\
\text { TAV }\end{array}$ & 28 & 13 & 46,43 & 15 & 53,57 \\
\hline Mean & 55 & 24 & 43,64 & 31 & 56,36 \\
\hline
\end{tabular}

Berdasarkan tabel 1 dapat dilihat siswa kelas $\mathrm{X}$ TEI belum lulus KKM sebanyak 16 orang dan siswa kelas X TAV sebanyak 15 orang. Terdapat berbagai faktor yang menyebabkan hasil belajar peserta didik kurang memenuhi standar KKM, salah satu penyebabnya adalah belum optimalnya media pembelajaran yang saat ini digunaan. Hal ini terlihat dari analisis observasi kebutuhan dan data ketuntasan hasil belajar. Dari analisis observasi kebutuhan siswa diperoleh hasil bahwa pelajaran DLE merupakan pelajaran yang menarik bagi siswa untuk dipelajari namun $75.41 \%$ peserta didik mengungkapkan bahwa waktu pembelajaran Dasar Listrik dan Elektronika hanya 4 jam tatap muka setiap minggunya dirasa kurang sehingga penyampaian materi dianggap kurang maksimal. 81,97\% siswa terkendala dalam memahami materi Dasar Listrik dan Elektronika karena materi yang dianggap sulit tanpa adanya media pendukung yang dapat membantu untuk memudahkan pemahaman. Karena beberapa kendala yang ditemukan maka dirasa perlu adanya media yang dapat mempermudah siswa agar maksimal memahami materi pembelajaran dimanapun ia berada agar dapat meningkatkan hasil belajar.

Bahan, keadaan wilayah, dan aktivitas yang dimanfaatkan agar dapat meningkatkan pengetahuan memperbaiki sikap, dan memberikan keterampilan pada setiap orang yang menggunakannya disebut media pembelajaran [8]. Media pembelajaran adalah perlengkapan pembelajaran yang digunakan sebagai perantara informasi dalam proses menambah pemahaman, memperbaiki sikap atau memberikan manfaat dalam pembelajaran. Informasi yang dimaksud merupakan materi belajar yang diberikan untuk siswa. 
Perkembangan teknologi telepon genggam berbasis android dari berbagai sisi, fitur yang lengkap yang sangat cepat dapat merangsang kita kreatif untuk memanfaatkannya untuk mendukung tahapan pembelajaran. Dengan menerapkan media pembelajaran ini diharapkan proses pembelajaran yang dilaksanakan bisa lebih membuat siswa aktif bertindak, kreatif berfikir, dapat memikirkan sesuatu yang baru dan menyenangkan. Media pembelajaran berbasis mobile learning adalah media pembelajaran yang dipersiapkan untuk membantu agar siswa lebih tertarik untuk belajar sesuai dengan tujuan pembelajaran. Menurut [9] mobile learning merupakan salah satu komponen yang dapat membantu dalam proses pendidikan dan pelatihan, dengan menggunakan media yang mobile, semacam PDA, Smartphone. Salah satu karakteristik dari m-learning adalah kemudahan dimana alat bisa dibawa, digunakan dimanapun, dan mudah digunakan.

Menurut [10] memanfaatkan m-learning pada pembelajaran membuat proses belajar tidak dibatasi ruang dan waktu, karena fleksibel dan portable sehingga siswa lebih aktif dalam belajar dan mudah digunaka. M-learning dapat dimanfaatkan sebagai alat belajar yang berisi materi pembelajaran. M-learning dapat berisi materi yang dibuat seoptimal mungkin agar mudah dipahami, dan latihan soal. Dari hasil penelitian diperoleh M-learning menggunakan handphone terbukti layak digunakan, praktis dan efisien dalam pembelajaran.

Berdasarkan penelitian sebelumnya disimpulkan bahwa pembelajaran berbasis $m$ learning dapat meningkatkan kualitas dan hasil pembelajaran. Hal ini juga dijelaskan[11] dalam penelitiannya memperoleh hasil pengembangan produk berbentuk media belajar yang dapat diakses menggunakan handphone agar meningkatkan keaktifan siswa karena fitur tampilan yang tidak membosankan. Menurut [12]model pembelajaran m-learning dapat memusatkan perhatian siswa sehingga dapat diterapkan pembelajaran siswa aktif (student centered learning) sehingga guru sebagai pengarah dalam pembelajaran. Setelah melakukan aktivitas belajar, seseorang akan mendapatkan hasil belajar. Pengalaman-pengalaman yang didapat oleh melingkupi ranah kognitif, afektif, dan psikomotor dapat diartikan sebagai hasil belajar [13]. Terjadinya perubahan dari pemahaman dan sifat siswa, termasuk juga perbaikan perilaku. Dari definisi tersebut, dapat ditarik kesimpulan hasil belajar adalah perubahan pemikiran, sifat, dan kemampuan siswa yang disebabkan oleh proses belajar merupakan output dari pembelajaran.

Berdasarkan pembahasan tersebut diperoleh kesimpulan bahwa SMK merupakan lembaga pendidikan pemerintah yang bertujuan mempersiapkan siswanya untuk menghadapi dunia kerja dengan perbekalan ilmu keterampilan yang dapat diterapkan di dunia kerja. Untuk memperoleh ilmu keterampilan tersebut siswa perlu berperan aktif dan memahami materi dengan gambaran nyata secara mudah. Upaya mempermudah kemampuan siswa dalam memahami pembelajaran DLE adalah dengan Pengembangan Media Pembelajaran. Dengan segala kelebihan yang disajikan oleh m-learning peneliti memilih mengembangkan media pembelajaran berbasis m-learning untuk mata pelajaran DLE pada Jurusan Teknik Elektronika Industri SMK N 4 Pariaman. Berdasarkan observasi awal guru mata pelajaran DLE berpendapat bahwa materi yang butuh pengembangan media yaitu sifat rangkaian seri, paralel dan campuran.

\section{METODA}

Penelitian ini menerapkan metode penelitian dan pengembangan yaitu kegiatan mengembangkan alat baru untuk menyempurnakan alat yang sudah ada. Pendapat [14] menyatakan metode yang digunakan pada penelitian untuk membentuk alat baru dan mengevaluasi seberapa efektif alat tersebut untujk diterapkan merupakan metode penelian penelitian dan pengembangan. Lebih lanjut [15], mendefinisikan R \& D sebagai Metode pengembangan bertujuan menciptakan produk dan alat pembelajaran dengan menilai atau mengevaluasi hasil pengembangan tersebut.

Penelitian ini mengikut model [16]Borg \& Gall mengungkapkan bahwa tahapan penelitian tersusun dalam sepuluh langkah penelitian yaitu, mengumpulkan informasi awal kendala yang ada pada proses pembelajaran, merencanakan produk dapat mengatasi permasalahan, pengembangan produk, uji validasi kepada ahli, revisi berdasarkan masukan ahli, percobaan awal, perbaikan alat, percobaan awal lapangan, perbaikan akhir, diseminasi dan pendistribusian. sepuluh langkah tersebut dikelompokan menjadi dua tahap pada penelitian ini. Pengelompokan tersebut dilakukan agar mempermudah proses penelitian, namun tidak mengurangi manfaat 
masing-masing tahapan yang sebenarnya. Kelompok tersebut yaitu :

1. Tahap Penelitian

Pada tahap penelitian dilakukan kegiatan sebagai berikut :

a. Menentukan desain awal media yang yang akan dikembangkan. Berdasarkan studi literatur disimpulkan m-learning cocok digunakan pada KD yang telah ditentukan pada tahap perencanaan.

b. Uji validitas diberikan kepada valiadtor materi dan ahli media untuk menilai apakah m-learning dapat diterapkan pada pembelajaran. M-learning juga didiskusikan dengan guru mata pelajaran DLE agar dapat melihat kelayakan $m$ learning.

c. Setelah diuji kevalidan m-learning oleh validator, dilakukan revisi media yang sesuai saranan validator. Revisi media merupakan proses penyempurnaan dari media yang dikembangkan sesuai dengan keperluan siswa di sekolah.

\section{Tahap Pengembangan}

Tahap Uji lapangan, adalah gabungan dari tahap percobaan awal lapangan, perbaikan akhir produk, diseminasi dan Penyebaran dan penyebaran media pembelajaran. Media pembelajaran yang telah melalui proses tahap pengembangan kemudian diterapkan dalam pembelajaran kelas eksperimen. Praktikalitas media pembelajaran diperoleh dari angket yang disebar kepada siswa sudah menerapkan media m-learning dalam pembelajaran. Nilai siswa kelas eksperimen dan kontrol digunakan untuk melihat seberapa efektifitas m-learning untuk meningkatkan nilai siswa.

\section{HASIL DAN PEMBAHASAN}

Pada tahap penelitian terdapat beberapa kegiatan yang dilakukan yaitu pengumpulan informasi, perencanaan, pengembangan produk pendahuluan, validasi, revisi, sehingga dihasilkan draf rancangan media pembelajaran. Setelah media selesai dibuat, selanjutnya akan diuji validasi media dan materi kepada ahli. Berikut pada tabel 2 dapat dilihat nilai Aiken's V yang berdasarkan pendapat ahli media.

Pada tabel 2 dapat dilihat rata-rata hasil validasi oleh ahli media sebesar 0,84 besar dari 0,3 sehingga dapat dikatakan valid. Berikut tampilan data Hasil Validasi Media Pembelajaran dalam bentuk grafik validitas media pembelajaran berbasis m-learning dapat dilihat pada gambar 1 .

Tabel 2. Hasil pendapat validator Media

\begin{tabular}{|c|c|c|c|c|c|c|c|}
\hline \multirow[t]{2}{*}{ No } & \multirow{2}{*}{ Aspek } & \multicolumn{3}{|c|}{$\begin{array}{c}\text { Skor } \\
\text { Penilaian } \\
\text { Validator }\end{array}$} & \multirow{2}{*}{$\sum \mathbf{s}$} & \multirow{2}{*}{$\begin{array}{l}\text { Aiken } \\
\text { 's V }\end{array}$} & \multirow{2}{*}{$\begin{array}{c}\text { Keterang } \\
\text { an }\end{array}$} \\
\hline & & $\begin{array}{l}\mathbf{V} \\
\mathbf{1}\end{array}$ & $\begin{array}{l}\mathrm{V} \\
2 \\
\end{array}$ & $\begin{array}{l}\mathbf{V} \\
\mathbf{3}\end{array}$ & & & \\
\hline 1 & Materi & 14 & 34 & 32 & 59 & 0.70 & Valid \\
\hline 2 & $\begin{array}{c}\text { Pembelajar } \\
\text { an }\end{array}$ & 21 & 27 & 26 & 56 & 0.78 & Valid \\
\hline \multicolumn{6}{|c|}{ Rata-Rata } & 0.74 & Valid \\
\hline
\end{tabular}

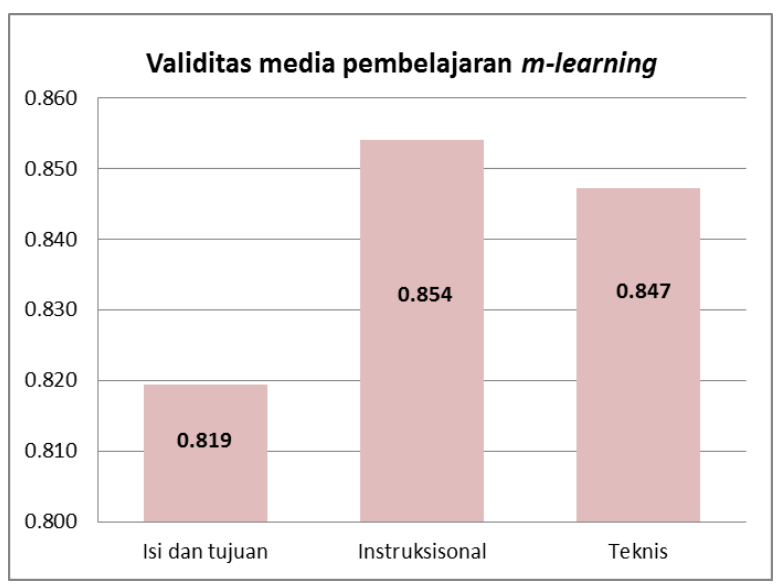

Gambar 1. Grafik Hasil Validasi Media Pembelajaran m-learning

Berdasarkan gambar 1 dapat dilihat hasil dari masing-masing item $>0,30$ sehingga media $m$ learning dapat dikatakan valid dan dapat diterapkan pada penelitian. Media pembelajaran juga diuji dari sisi pembahasan materi terdapat pada m-learning. Pada angket validasi materi terdapat aspek materi dan pembelajaran. Untuk lebih rinci hasil validitas dari ahli materi dapat dilihat pada tabel 3 .

Tabel 3. Hasil Validasi Materi

\begin{tabular}{|c|c|c|c|c|c|c|c|}
\hline \multirow{2}{*}{ No } & \multirow{2}{*}{ Aspek } & \multicolumn{3}{|c|}{$\begin{array}{c}\text { Skor Penilaian } \\
\text { Validator }\end{array}$} & \multirow{2}{*}{$\sum \mathbf{s}$} & \multirow{2}{*}{$\begin{array}{l}\text { Aiken' } \\
\text { s V }\end{array}$} & \multirow{2}{*}{$\begin{array}{c}\text { Keteran } \\
\text { gan }\end{array}$} \\
\hline & & V1 & V2 & V3 & & & \\
\hline 1 & $\begin{array}{c}\text { Isi } \\
\text { dan } \\
\text { Tujuan }\end{array}$ & 22 & 28 & 27 & 59 & 0.82 & Valid \\
\hline 2 & $\begin{array}{c}\text { Instruk } \\
\text { sional } \\
\end{array}$ & 32 & 39 & 35 & 82 & 0.85 & Valid \\
\hline 3 & Teknis & 24 & 28 & 27 & 61 & 0.85 & Valid \\
\hline \multicolumn{6}{|c|}{ Rata-rata } & 0.84 & Valid \\
\hline
\end{tabular}


Berdasarkan tabel 3 dapat dilihat rata-rata hasil validasi materi sebesar 0,74 yang besar dari 0,3 sehingga dikategorikan valid. Pada gambar 2 disajikan tampilan data Hasil Validasi materi dalam bentuk grafik :

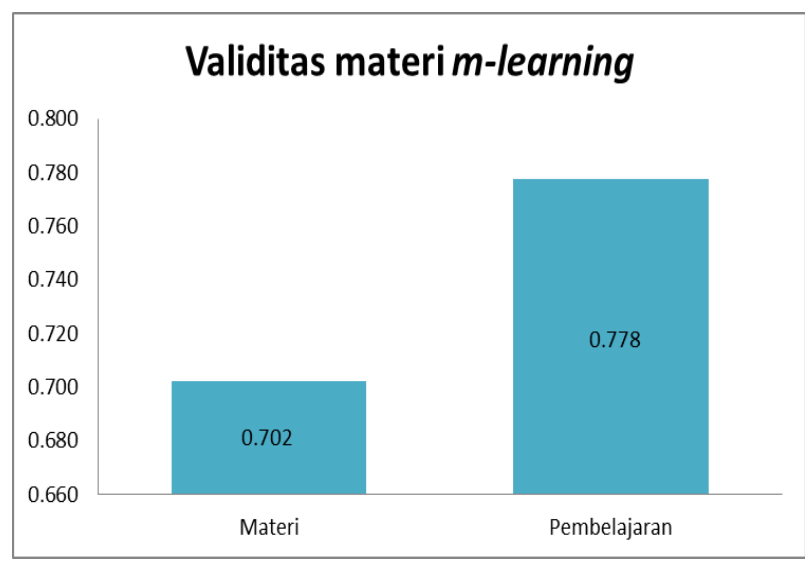

Gambar 2. Grafik Hasil Validasi materi $m$ learning

Berdasarkan gambar 2 dapat dilihat hasil dari masing-masing item $>0,30$ sehingga materi pada m-learning dapat dikatakan valid dan dapat diterapkan pada penelitian. Pada tahap pengembangan, m-learning yang sudah teruji dilakukan penyebaran media pembelajaran $\mathrm{m}$ learning kepada siswa kelas eksperimen. Proses pembelajaran ditunjang dengan menggunakan media pembelajaran m-learning yang sudah diuji validitasnya. Berikut tampilan awal media terdapat pada gambar 3 :

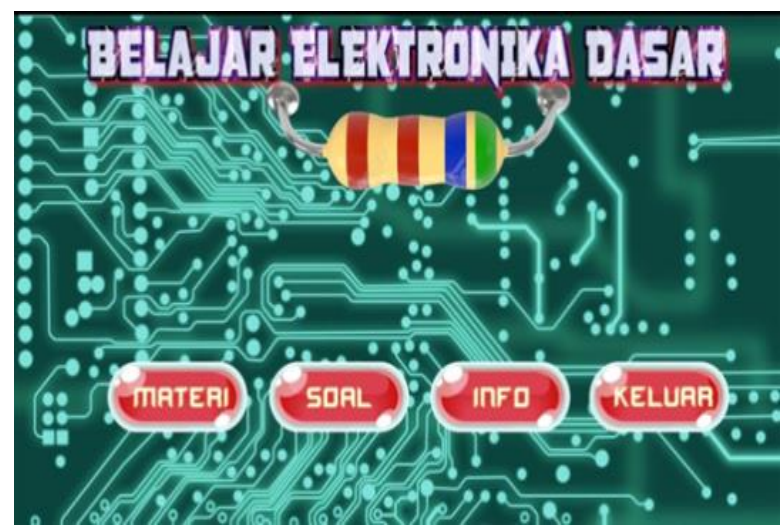

Gambar 3. Tampilan awal media

Berdasarkan gambar 3 dapat dilihat tampilan awal media berisi fitur materi, materi disajikan secara ringkas. Soal latihan yang berisi tiga tingkatan kesulitan soal, yaitu mudah, sedang dan sulit sehingga siswa dapat mengukur kemampuannya dengan mengerjakan soal tersebut. Selanjutnya pada gambar 4 terdapat pilihan materi pada fitur materi.

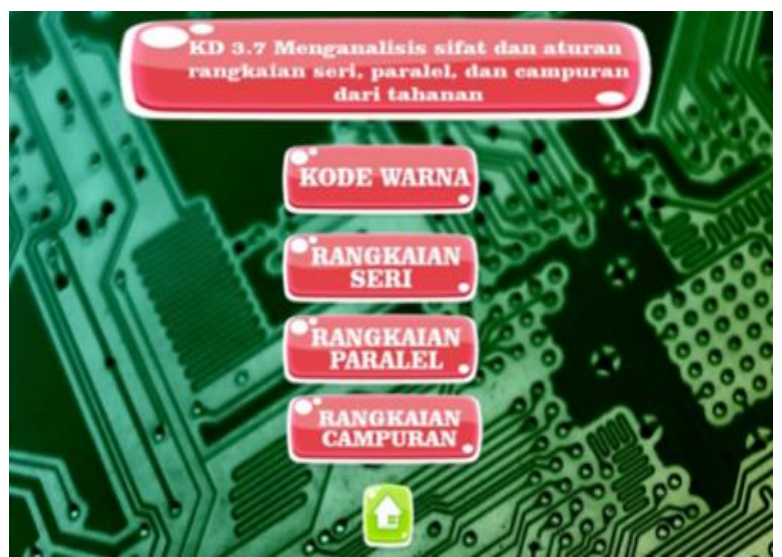

Gambar 4. Tampilan menu dalam materi

Berdasarkan gambar 4 dapat dilihat bahwa penelitian ini diterapkan pada Kompetensi Dasar ke 7 yang membahas materi kode warna resistor, rangkaian seri, rangkaian paralel dan rangkaian campuran. Materi disajikan secara ringkas agar siswa lebih mudah memahami materi pembelajaran. Pada gambar 5 dapat dilihat materi pembelajaran yang disajikan pada m-learning.

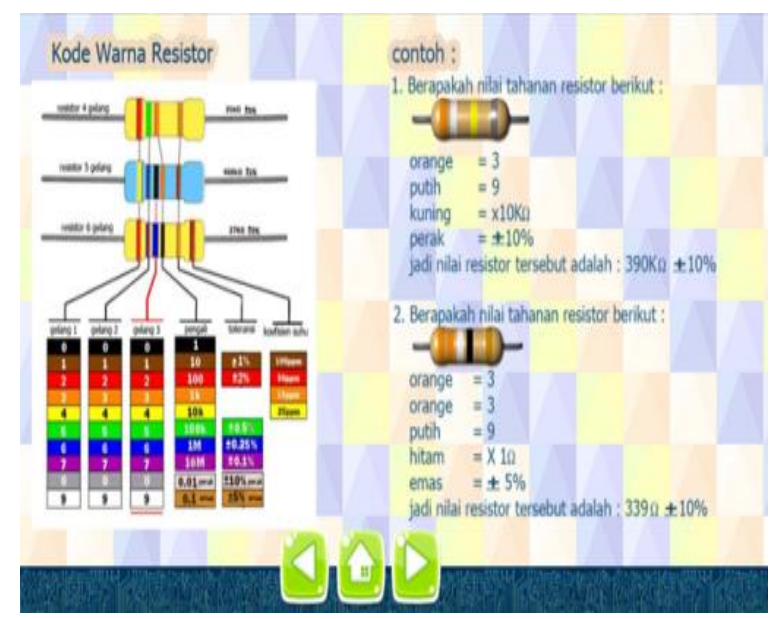

Gambar 5. Tampilan dalam materi

Berdasarkan gambar 5 merupakan tampilan dalam materi dengan variasi gambar yang beragam agar lebih menarik dan meningkatkan minat siswa untuk mempelajarinya. Pada gambar 6 dapat dilihat bentuk soal latihan yan ada pada m-learning.

Berdasarkan gambar 6 dapat dilihat bentuk soal latihan yang ada pada media. Siswa menjawab dengan cara menggeser jawaban yang benar ke kotak jawaban yang sudah disediakan. Setelah siswa dan guru memanfaatkan media pembelajaran maka diuji seberapa praktis media 
tersebut digunakan dalam pembelajaran. Uji praktikalitas terdiri dari 14 butir angket dari 16 butir angket uji coba yang telah diuji kevalidannya, dan ke ajegannya. 14 butir soal yang valid, digunakan untuk uji praktikalitas guru dan siswa. Praktikalitas bertujuan untuk melihat kemudahan dalam penggunaan media pembelajara berbasis $m$-learning.

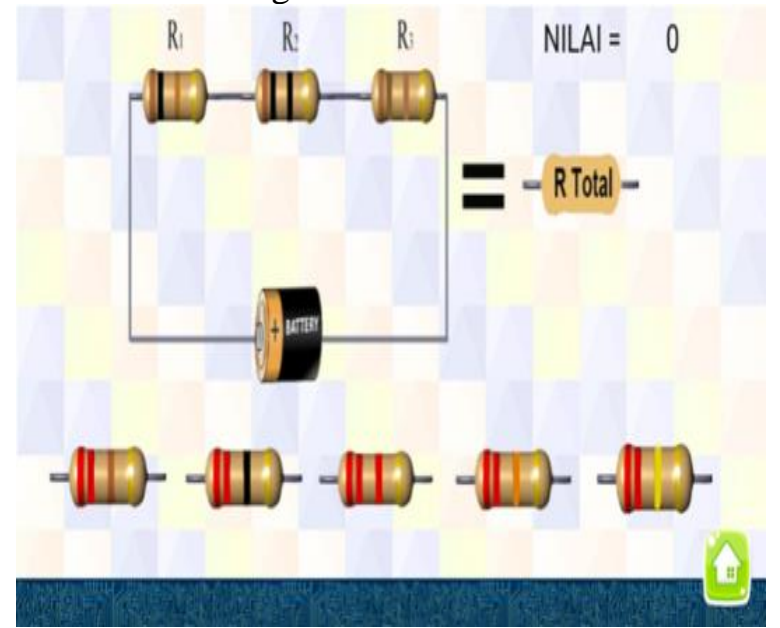

Gambar 6. Tampilan dalam soal

Data praktikalitas diperoleh melalui pendapat satu orang guru mata pelajaran DLE yang dituangkan pada angket penelitian. Dari pendapat guru dapat diperoleh kesimpulan apakah $m$ learning yang dikembangkan dari aspek Kualitas Produk, Penyajian Materi, dan Manfaat praktis untuk digunakan. Hasil angket secara rinci dapat dilihat pada tabel 4 .

Tabel 4. Hasil praktikalitas dari pendapat guru

\begin{tabular}{|c|c|c|c|}
\hline No & Aspek & Persentase & Kategori \\
\hline 1 & Kualitas Produk & 92 & Sangat Praktis \\
\hline 2 & $\begin{array}{c}\text { Penyajian } \\
\text { Materi }\end{array}$ & 96.67 & Sangat Praktis \\
\hline 3 & Manfaat & 93.33 & Sangat Praktis \\
\hline \multicolumn{2}{|c|}{ Rata-Rata } & 94 & Sangat Praktis \\
\hline
\end{tabular}

Berdasarkan Tabel 4 dapat dilihat rata-rata kepraktisan media menurut pendapat guru yaitu $94 \%$, sehingga media pembelajaran berbasis $m$ learning tersebut berada pada rentang $81 \%$ sampai $100 \%$ disimpulkan termasuk kategori "sangat praktis". Hasil praktikalitas pendapat guru mengenai media pembelajaran m-learning dapat dilihat pada gambar 7 berikut :

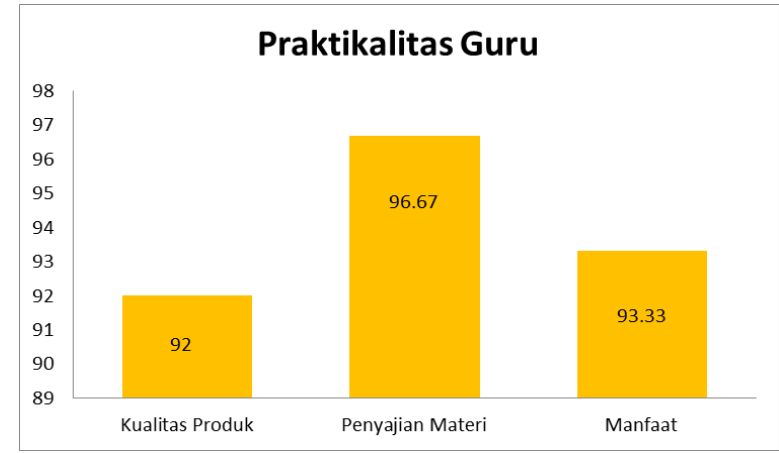

Gambar 7. Grafik Hasil Angket praktikalitas Respon Guru

Uji praktikalitas juga diperoleh dari pendapat siswa yang menggunakan m-lerning pada pembelajarannya yaitu siswa kelas $\mathrm{X} \mathrm{TEI}_{\mathrm{A}}$ yang menjadi kelompok eksperimen. Siswa mengisi angket praktikalitas sesuai dengan pendatnya mengenai m-learning pada aspek kualitas produk, penyajian materi, dan manfaat. Pendapat siswa pada angket praktikalitas dapat dilihat secara rinci pada tabel 5 berikut :

Tabel 5. Hasil Angket Respon Peserta didik

\begin{tabular}{|c|c|c|c|}
\hline No & Aspek & Persentase & Kategori \\
\hline 1 & Kualitas Produk & 89.38 & Sangat Praktis \\
\hline 2 & Penyajian Materi & 82.29 & Sangat Praktis \\
\hline 3 & Manfaat & 81.04 & Sangat Praktis \\
\hline \multicolumn{2}{|c|}{ Rata-Rata } & 84.24 & Sangat Praktis \\
\hline
\end{tabular}

Berdasarkan tabel 5 dapat rata-rata hasil uji kepraktisan m-learning oleh siswa yaitu $84,24 \%$, berada pada rentang $81 \%$ sampai $100 \%$ disimpulkan termasuk kategori "sangat praktis". Hasil praktikalitas pendapat siswa mengenai media pembelajaran m-learning dapat dilihat pada gambar 8 .

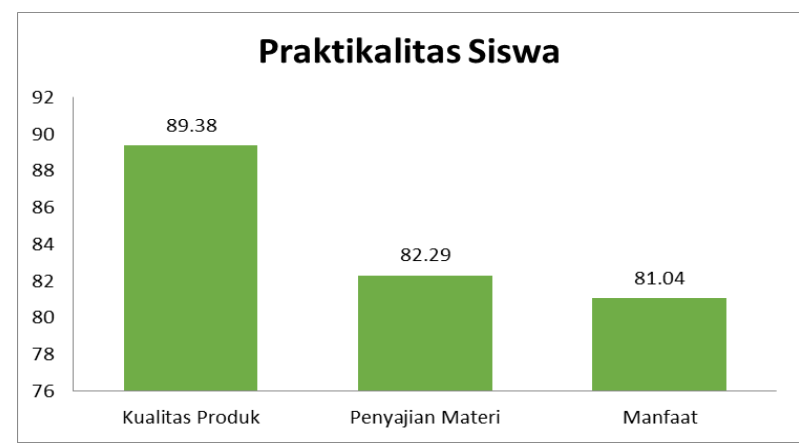

Gambar 8. Grafik Hasil Angket praktikalitas Respon siswa 
Berdasarkan hasil penelitian [17] m-learning sangat layak untuk digunakan sebagai salah satu media pembelajaran dikelas. M-learning ini praktis digunakan dalam pembelajaran. Sehingga aplikasi m-learning yang dioperasikan menggunakan handphone dengan sistem informasi android adalah sangat layak digunakan. Hal tersbut sejalan dengan penelitian ini dimana analisis penelitian, m-learning ini dikembangkan untuk memabantu siswa untuk memhami materi pembelajaran. Selain itu pengembangan media pembelajaran ini juga dikarenakan belum tersedianya media pembelajaran yang bisa membantu siswa untuk belajar secara aktif dan mandiri yang tidak terbatas dengan tempat dan waktu, sehingga siswa dapat belajar kapan dan dimanapun baik secara mandiri. Dengan menggunakan media pengembangan ini siswa dapat mempelajari materi-materi pembelajaran sesuai dengan kurikulum yang telah ditentukan yang dilengkapi dengan berbagai fasilitas pembelajaran diantaranya, materi pembelajaran, simulasi materi, dan soal latihan.

Soal latihan telah menggunakan tipe soal Higher Order Thinking Skills (HOTS). Menurut [18] istilah HOTS merupakan proses berpikir dengan cara yang lebih tinggi daripada penghafalan, atau menjelaskan kembali sesuatu yang pernah disampaikan orang lain. Soal yang disajikan tidak mudah langsung tertebak jawabannya, siswa harus menganalisis terlebih dahulu maksud soal sesungguhnya setelah dipahami maksud soal kemudian siswa menganalisis jawaban dan kemudian memikirkan kembali makna yang tersirat dari jawaban objektif yang telah tersedia sehingga ditemukan jawaban yang benar. Dengan adanya soal latihan dengan HOTS ini diharapkan siswa menjadi terbiasa atau terdorong untuk belajar lebih giat.

Pada penelitian relevan belum ditemukan adanya simulasi pada materi. Simulasi dari materi bertujuan agar siswa lebih mudah mengingat materi. Simulasi dapat dilakukan berulang kali sampai siswa merasa cukup untuk paham. $M$ learning yang dikembangkan oleh peneliti terdahulu berupa materi yang terdapat pada modul kemudian dituangkan pada media smartphone sehingga siswa bisa membaca materi dimanapun dan kapanpun [19]. Pada media m-learning yang dikembangkan pada saat ini disajika hanya ringkasan teori sehingga siswa tidak perlu membaca terlalu banyak materi untuk memahami pelajaran yang akan dipahami. Dengan materi yang sudah dirangkum siswa akan mudah mengingat materi yang dibahas untuk melanjutkan kepada latihan soal. Media pada penelitian lainnya juga menggunakan soal latihan, namun belum memiliki tingkat kesukaran soal dan tipe soal HOTS. Untuk tipe soal HOTS juga belum digunakan pada media sebelumnya. Soal latihan berupa soal objektif biasa dimana saat membaca soal kita sudah dapat menebak kemungkinan jawaban yang akan dipilih. Dengan beberapa pembahasan tersebut diharapkan m-learning yang dibuat ini dapat membantu pemahaman siswa dalam memahami pembelajaran.

\section{KESIMPULAN}

Validator media memvalidasi media pada aspek isi, tujuan, instuksional dan teknis termasuk kategori valid. Validasi materi pada aspek materi dan pembelajaran yang ada pada media telah diujikan kepada validator materi dan diperoleh kategori valid. Nilai praktikalitas diperoleh dari hasil pendapat guru dan siswa yang menggunakan m-learning pada proses pembelajaran dilihat dari pada aspek kualitas produk, penyajian materi dan manfaat media dikategorikan sangat praktis. Hasil belajar siswa digunakan untuk melihat seberapa efektif m-learning digunakan pada pembelajaran. Dari nilai posttest siswa diperoleh hasil efektifitas menggunakan uji $U$ test Mann Whitney dapat disimpulkan sehingga dapat disimpulkan terdapat perbedaan yang mencolok hasil belajar siswa yang memanfaatkan m-learning dalam pembelajaran dengan hasil belajar siswa dengan belajar seperti biasa.

\section{DAfTAR PUSTAKa}

[1] J. Dewey, Democracy in Education. New York: MC Millan, 2003.

[2] F. Ihsan, Dasar-dasar Kependidikan. Jakarta: Rineka Cipta, 2005.

[3] O. Hamalik, Proses Belajar Mengajar. Jakarta: Bumi Aksara, 2001.

[4] A. Horowitz, Returns to general, technical and vocational education in developing. Education Economics, 2006.

[5] M. Houten and M. Van, "Vocational education and the binary higher education system in the Netherlands: higher education symbiosis or vocational education dichotomy," J. Vocat. Educ. Train., 2017.

[6] S. Billet, Vocational Education, Purpose, Traditions, and Prospects. New York: Spinger, 2011.

[7] M. M. van Houten, "Vocational education and 
the binary higher education system in the Netherlands: higher education symbiosis or vocational education dichotomy" J. Vocat. Educ. Train., vol. 70, no. 1, pp. 130-147, 2018.

[8] N. Sudjana and A. RIvai, Media Pengajaran. Bandung: Sinar Baru Algansindo, 2013.

[9] D. Keegan, Mobile Learning: The Next Generation of Learning. London: Routledge, 2005.

[10] Sugiyono, Metode Penelitian Pendekatan Kualitatif, Kuantitatif dan $R \& D$. Bandung: Alfabeta, 2015.

[11] Lu'mu, "Learning Media Of Applications Design Based Android Mobile Smartphone," Int. J. Appl. Eng. Res., vol. 12, no. 17, 2017.

[12] G. Amirullah and R. Hardinata, "Pengembangan mobile learning bagi pembelajaran.” J. Kesejaht. Kel. dan Pendidik., vol. 4, no. 2, pp. 97-101, 2017.

[13] W. Hapsari, H. Wibawanto, and I. M. Sudana, "Pengembangan Mobile Learning Teknik Digital Bagi Mahasiswa Pendidikan Teknik Elektro," J. Vocat. Career Educ., vol. 2, no. 1, 2017.

[14] Rusman and Dkk, Pembelajaran Berbasis Teknologi Informasi dan Komunikasi. Jakarta: PT. Raja Grafindo Persada, 2013.

[15] W. Sanjaya, Media Komunikasi Pembelajaran. Jakarta: Kencana, 2014.

[16] C. R. Richey and J. D. Klein, Design and development research methods, strategies and issue. Lawrence Erbaum Associates, Inc, 2007.

[17] W. R. Borg and M. D. Gall, Educational research: An Introductional. New York: Longman, 2003.

[18] M. R. L. Alhafidz and A. Haryono, "Pengembangan Mobile Learning Berbasis Android Sebagai Media Pembelajaran Ekonomi," J. Pendidik. Ekon. vol. 11, no. 2, pp. 118-124, 2018.

[19] A. Thomas and G. Thorne, "Parents And Teachers Can Do A Lot To Encourage Higher Order Thinking. Here Are Some Strategies to Help Foster Children's Complex thinking," J. ERIC Clear. Urban Educ., 2009.

\section{Biodata Penulis}

Mery Sumiati, lahir di Padang, 7 Maret 1994. Sarjana Pendidikan di Jurusan Teknik Elektronika FT UNP 2015. Tahun 2016 melanjutkan pendidikan di Jurusan Teknologi Pendidikan Kejuruan, Program Pascasarjana Fakultas Tenik UNP dengan bidang konsentrasi Pendidikan Teknik Elektronika dan bekerja paruh waktu di Sekolah Menengah Kejuruan Negeri 4 Pariaman.

Fahmi Rizal, Lahir di Kamang Mudik tanggal 4 Desember 1959. Beliau lulus Sarjana (S1) pada tahun 1983 di Jurusan Teknik Bagunan IKIP Padang, Magister Pendidikan (S2) di IKIP Jakarta pada tahun 1992, Magister Teknik (S2) UGM Yogyakarta Pada Tahun 2000, dan Doktor (S3) dan Bidang Ilmu Pendidikan di Universitas Negeri Jakarta Pada Tahun 2007.

Muhammad Anwar, lahir di Kutulu, 05 Agustus 1973. Sarjana Pendidikan di Jurusan Teknik Elektronika FT IKIP Padang Tahun 1996. Tahun 2001 memperoleh gelar Magister Teknik di Universitas Gajah Mada. Memperoleh gelar Doktor di Universitas Negeri Yogyakarta pada tahun 2016. Staf pengajar di jurusan Teknik Elektronika sejak tahun 2005. 